\title{
Interpretacje
}

\section{Część śmierci: bierny frankizm i czarna gnoza w Piotrusiu Leo Lipskiego}

Adam Lipszyc

TEKSTY DRUGIE 2017, NR 2, S. 333-355

DOI: $10.18318 /$ td.2017.2.19

W roku 1967 minipowieść Piotruś ukazała się w niemieckim przekładzie Oskara Tauschinskiego. Pismo „Die Zeit” zamówiło recenzję książki Lipskiego u Ingeborg Bachmann'. Recenzja nigdy nie powstała, zachował się jednak jej szkic, który z pewnością jest czymś więcej niż tylko notatką z lektury: to parę niemal gotowych akapitów, czasem w kilku wariantach ${ }^{2}$. Trudno orzec, dlaczego Bachmann nie ukończyła recenzji, jak można jednak sądzić na podstawie zachowanych fragmentów, nie stało się tak bynajmniej dlatego, że nie była prozą Lipskiego dostatecznie zaintrygowana.

Autorka Maliny z rozbawieniem odnotowuje fakt a najwyraźniej od tej kwestii chciała rozpocząć recenzję
Adam Lipszyc

(ur. 1975) - eseista i tłumacz, pracuje w Instytucie Filozofii i Socjologii PAN, uczy w Szkole Nauk Społecznych, w Collegium Civitas oraz na Uniwersytecie Muri im. Franza Kafki. Ostatnio opublikował książkę Czas wiersza. Paul Celan i teologie literackie (2015). Kontakt: adamlipszyc@ gmail.com

1 Zob. S. Weigel Ingeborg Bachmann, Paul Zsolnay Verlag, Wien 1999, s. 290 i $495-496$.

2 Zob. I. Bachmann Ein Maximum an Exil (über Leo Lipski), w: tejże Kritische Schriften, Piper Verlag, München 2005, s. 439-449. Dziękuję Nassimie Sahraoui z Uniwersytetu Muri im. Franza Kafki, która udostępniła mi kopię tego tekstu. 
- że książka Lipskiego stała się przedmiotem zainteresowania wiedeńskiego parlamentu i austriackiego Ministerstwa Spraw Wewnętrznych: polskiego pisarza posądzono mianowicie o uprawianie pornografii. Bachmann oddala ten zarzut jako niedorzeczny, podobnie myląca i groteskowa wydaje się jej też jednak notka, którą opatrzono niemiecki przekład Piotrusia. Otóż na okładce książki wydawca informuje czytelnika, że - obok znanych już w świecie niemieckojęzycznym Szmuela Josefa Agnona i Dawida Rokeacha - Lipski to „nowy głos z Izraela”3. Tymczasem, jak trzeźwo zauważa Bachmann, proza Lipskiego nie należy do literatury izraelskiej i nawet nie przełożono jej dotąd na hebrajski (jeśli nie liczyć kilku opowiadań, jest tak zresztą do dziś). Jest to raczej jedna z „utraconych książek”, które mówią o pewnej rzeczywistości społecznej pozostającej w okresie przejściowym, mówią o niej jednak w języku obcym wobec tej rzeczywistości, jedna z książek, które Bachmann określa nader sugestywnym mianem die Niemandslandbücher, książek z Niczyjkraju4.

Mimo to, stroniąc od socjologii i polityki, mocą „radykalizmu człowieka głęboko nieszczęśliwego" Lipski zdołał - wedle Bachmann - napisać „pierwszą książkę o Izraelu", książkę, która wszakże odsłania podwójny grunt czy podwójne dno tego kraju ${ }^{5}$. W oczach Lipskiego bowiem „Ziemia Obiecana okazuje się najbardziej oddalona od samej siebie. Ci, którzy do niej przy-

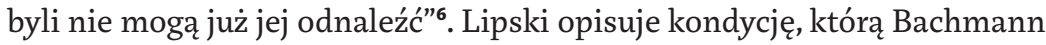
określa mianem „maksimum wygnania” (taki tytuł miała nosić jej recenzja), wygnania w „kraju, do którego nie można przybyć na dobre, gdzie zamyka się zapadnia i oto człowiek znajduje się najdalej od swojego miejsca pochodzenia"7. Stąd też w zapiskach Bachmann fraza das Niemandslandbuch odnosi się nie tylko do specyficznego językowego statusu Piotrusia. Niczyjkraj to właśnie najlepsza charakterystyka żydowskiej społeczności w Palestynie, a przynajmniej owego drugiego dna Kraju Izraela, które odsłania się w narracji Lipskiego. Pisze bowiem Bachmann: „To książka z Niczyjkraju, za scenerię ma bowiem kraj, do którego człowiek przybywa, tym samym jednak znajduje

3 Tamże, s. 441.

4 Tamże, s. 447-448.

5 Tamże, s. 445-446.

6 Tamże, s. 444.

7 Tamże, s. 439. 
się w pewnej nieosiągalnej dali”. Owa „nieosiągalna dal” przywodzi na myśl „daleką obczyznę”, o której w Zamku pisze Franz Kafka:

K. nieustannie miał poczucie, że błądzi lub znajduje się na tak dalekiej obczyźnie, gdzie nawet powietrze nie ma tych samych składników, co w kraju ojczystym, gdzie obcość dławi, a wśród jej szalonych powabów nie można nic innego zrobić, tylko dalej brnąć i błądzić. ${ }^{9}$

Nawiązując do tego fragmentu, Walter Benjamin komentuje:

Powietrze w tej wiosce [pod górą zamkową] nie jest wolne od woni zjawisk nieuformowanych i przejrzałych, które tworzą tak obmierzłą mieszankę. Kafka musiał nim oddychać przez całe życie. ${ }^{10}$

Wygląda więc na to, że - w ujęciu Bachmann - ową najdalszą obczyznę, swoją wioskę pod górą zamkową, Leo Lipski odnalazł w domniemanym centrum żydowskiego świata.

To bardzo trafna charakterystyka uniwersum Piotrusia. Istotnie, w swoim arcydziele Lipski opisuje Palestynę niedookreślonego roku „194...” jako przestrzeń skrajnego wyobcowania. Nic nie jest tu swojskie, także na poziomie języka i fabuły. Czytelnika na każdym kroku czeka nieprzyjemne zaskoczenie, a pierwszy szok, z którego nie możemy otrząsnąć się właściwie aż do końca lektury, przychodzi już w pierwszym mikrorozdziale powieści, kiedy to inwalida Piotruś wystawia się na sprzedaż „WRAZ Z ODZIEŻĄ”1 . Ta przestrzeń alienacji jest także przestrzenią chaotycznego wiru, istnego tohu wa-wohu, do którego oto powraca świat stworzony. Owo wielkie pomieszanie dotyka rozmaitych poziomów rzeczywistości. Przede wszystkim jest to chaos materii. Drugi rozdział powieści rozpoczyna się od sugestywnego opisu buzującego targowiska na pograniczu Tel Awiwu i Jafy:

8 Tamże, s. 446.

F. Kafka Zamek, przeł. K. Truchanowski, K. Radziwiłł, Czytelnik, Warszawa 1958, s. 74.

W. Benjamin Franz Kafka, przeł. A. Lipszyc, w: tegoż Konstelacje, przeł. A. Lipszyc, A. Wołkowicz, Wydawnictwo UJ, Kraków 2012, s. 242-243.

11 L. Lipski Piotruś (Apokryf), w: tegoż Powrót, opr. A. Maciejowska, Instytut Literacki Kultura Instytut Książki, Paryż-Kraków 2015, s. 201. Dalsze odniesienia do tego tomu w tekście, wraz z numerem strony. 
Targ wielki, nieustający jarmark, bazar właściwie, suk lub szuk. Rojna, długa ulica, gdzie chodziło się z trudnością, o przecznicach pachnących drobiem i mięsem. Przecznice te, pozornie podobne do włoskich uliczek, spadały ku morzu, wiecznie mruczącemu. Można tu było kupić po cenach znacznie zaniżonych takie rzeczy jak grzebyki, kury, majtki jedwabne, pomarańcze, korale, nieskończoną ilość przedmiotów dużych i małych, nawalonych często kupą, przewyższającą człowieka. (s. 201)

Co ważniejsze, ów wir chaosu wciąga też oczywiście ludzi. Być może tylko jeden z nich - Piotruś - pomieszany z rzeczami sprzedaje się na targu jak kawał mięsa, inni jednak nie są w o wiele lepszej sytuacji: palestyński Niczyjkraj jest przestrzenią całkowitej erozji wszystkich życiowych projektów, wręcz samego czasu, który winien przecież nadawać strukturę narracji ludzkiego życia. Podczas chamsinu Piotruś medytuje:

Przyjeżdża się z planami. Każda godzina jest droga. I tu dzieje się rzecz nieoczekiwana. Czas rozkłada się. Pomału, pomału wsiąka się w to wszystko. Ostrze tępieje. Dewastacja umysłu przez światło. Półrocze i lata. Porusza się jak w bagnie. Opada się. Arabieje. (s. 216)

Wreszcie, Palestyna jawi się tutaj jako domena wielkiego pomieszania narodów, coś w rodzaju inwersji utopijnej Jerozolimy jako miasta pokoju wszystkich ludów. Pogrążony w rozpaczy sąsiad Piotrusia, Żyd z Polski, mówi do swojej żony:

Nie szalej, proszę, nie szalej. Możesz mieć kochanków oficerów polskich, angielskich, australijskich. Murzynów. Możesz robić anatomię porównawczą członków różnych narodów. (s. 210)

Jest jeszcze jedna sfera, w której panuje chaos. Świat Piotrusia to roztrzaskana Wieża Babel przeniesiona do Palestyny, przestrzeń, w której wirują wszystkie języki, a język jako taki ulega rozpadowi. Gdy Piotruś wystawia się na sprzedaż, wywiesza nad swoją głową szyld w trzech językach (s. 201). Gdy na polecenie pani Cin, która kupiła go na targu, inwalida blokuje wspólny klozet, by tym samym skłonić lokatorów swojej właścicielki do wyprowadzki, ci błagają go, by wyszedł, „we wszystkich językach” (s. 211). Sąsiedzi (ci od porównawczych studiów nad penisami różnych nacji) lamentują, że ich córka utraci ojczystą polszczyznę na rzecz hebrajskiego, już teraz bowiem 
robi po polsku śmieszne błędy (s. 209-210). Wreszcie, gdy Edka, brutalny syn pani Cin, czyta gazetę, Piotrusiowi wydaje się, że ten tylko „udaje, że czyta, bo te znaki nic nie znaczą" (s. 205). W rozdziale piętnastym narrator mówi zaś całkiem otwarcie:

Język, którym myślę, rozpada się i kruszy. Jest niby-mamrotaniem starych kobiet, co moczą biszkopty w mleku. Gwałtowna atrofia: kurczę się. (s. 213)

Warto zresztą zwrócić uwagę, że w tym właśnie rozdziale Lipski prezentuje sam ów proces erozji języka w działaniu. Tworzy tutaj jawnie heterogeniczny dyskurs, w którym głos narratora przeplata się z nie zawsze wyraźnie odróżnionymi wypowiedziami pani Cin; ponieważ Piotruś mówi tu również „Jestem sam” (s. 212), istnieje zresztą możliwość, że wypowiedzi pani Cin to tylko akustyczne halucynacje udręczonego inwalidy. W dyskurs ten wpisane zostają dwa poprawnie zreprodukowane cytaty (s. 212), jeden z Martina Heideggera i jeden z Carla Gustava Junga (odpowiednio: z Czym jest metafizyka? i Das Seelenproblem des modernen Menschen), które poniekąd nadają temu fragmentowi powieści charakter rozprawy filozoficznej ${ }^{12}$. Co najważniejsze jednak, znaczną część tego rozdziału wypełniają mniej lub bardziej oderwane akapity szczękliwego wywodu, aforyzmy, rozważania, mikronarracje, przy czym wiele z pomieszczonych tutaj zdań to fragmenty tzw. egotyków, krótkich utworów Lipskiego pisanych prozą poetycką ${ }^{13}$. Pisarz cytuje więc samego siebie, stłaczając czy wręcz zgniatając fragmenty swojego dyskursu w jednym krótkim rozdziale-montażu. Najciekawsze wydaje się to, co dzieje się w pierwszym akapicie. Oto w jednym z egotyków czytamy: „Ludzie odpadają ode mnie, jak liście z więdnącego drzewa"14. Piętnasty rozdział Piotrusia zaczyna się natomiast tak: „Życie osiada na twarzy jak pył. Ludzie odpadli ode mnie. Tynk. Liście jesienią" (s. 212). Tym samym nieco pretensjonalne zdanie, które ma opisywać rozpad więzi łączących podmiot z otoczeniem, samo ulega PWN, Warszawa 1999, s. 107; C.G. Jung Das Seelenproblem des modernen Menschen, w: tegoż
Gesammelte Werke, t. 3. Patmos, Ostfildern 2011, s. 92. menty, które - czasem po przetworzeniu - weszły do piętnastego rozdziału Piotrusia, na s. 47 ,
$48,53,55,78$. 
metodycznie przeprowadzonemu procesowi rozpadu. Słówko „jak” ustanawiające symbolistyczną analogię między atrofią relacji międzyludzkich i jesiennym kresem wegetacji zostaje wyeliminowane, w jego miejsce pojawia się zaś równoważnikowy „tynk”, który bardziej chciałby połączyć się z „pyłem” z pierwszego zdania, ale i on odpadł, oderwał się od gramatyczno-logicznego ciągu. Po mistrzowsku krzyżując dwa szeregi porównań, Lipski w sposób nader wyrazisty pokazuje, że o rozpadzie nie sposób mówić językiem, który sam rozpadowi nie uległ. Nic też dziwnego, że kolejny akapit rozpoczyna się zdaniem, które - choć nominalnie odnosi się do słów pani Cin - mówi też o tym, co przed chwilą stało się z dyskursem narratora: „Opadają wyrazy szeptane w mroku" (s. 212).

Pośród przykładów babelicznego rozpadu języka jeszcze jeden zasługuje na szczególną uwagę. W rozdziale dziesiątym Piotruś, który sam jąka się i sepleni (s. 203), śledzi awanturę dwóch prostytutek pracujących w podwórzu domu pani Cin ${ }^{15}$. Jedna z nich - głuchoniema - „krztusi się i wyje”, by następnie wyrzucić z siebie taki oto ciąg sylab: „aba, aba, bababa, bababa” (s. 209). Jeśli nie oprzemy się pokusie dopatrzenia się jakiegoś połamanego sensu w tej kulawej sekwencji dźwięków, moglibyśmy dojść do wniosku, że nieszczęsna kobieta stara się przywołać jakiegoś nieobecnego ojca (lub Ojca): „aba” to po hebrajsku ojciec. Idąc o krok dalej tą niepewną ścieżką, moglibyśmy też wysunąć hipotezę, że próbuje ona zarazem nazwać owo miejsce opuszczone przez ojca, miejsce, w którym ona, Piotruś i wszyscy inni utkwili. Owo miejsce to ruiny wieży Babel, którą prostytutka nazywa w sposób jak najtrafniejszy właśnie wówczas, gdy nie udaje jej się wypowiedzieć jej pełnej nazwy: tylko rozbita mowa głuchoniemej - „bababa, bababa” - nazywa to rozbite miejsce.

Babeliczny chaos rzeczy, ludzi, członków i słów krąży wokół osiowego punktu, jakim jest klozet pani Cin, pod którego drzwiami lokatorzy zanoszą błagania „we wszystkich językach”. Ów klozet, kiBel, wyznacza straszliwą dziurę w samym środku roztrzaskanej wieży BaBel. Stawiając sprawy w ten sposób, Lipski intensyfikuje jedynie tendencję, która obecna jest w całej jego prozie. Nie jest bowiem tajemnica, że klozety, fekalia i sfera analna w ogólności odgrywają w jego pisarstwie rolę zasadniczą. Z wyjątkiem Pradawnej opowieści oraz Miasteczka nie ma tekstu prozatorskiego, w którym autor

15 Dom mieści się przy wyimaginowanej ulicy Chapu-Chapu 8. Sam Lipski mieszkał w Tel Awiwie przy ulicy Mapu 8, także i w tej transformacji mamy więc bodaj do czynienia z zająkliwą deformacją mowy, a zarazem topografii miasta. 
Piotrusia w taki czy inny - zazwyczaj bardzo dobitny - sposób nie odnosił się do tej sfery. Sam klozet jest dlań naznaczony szeregiem rozmaitych, czasem sprzecznych sensów. I tak, Lipski całkiem jawnie mówi o erotycznym wymiarze tego miejsca i samego aktu defekacji. Wspominając pobyt w Iranie, Piotruś opowiada o niejakim panu Bujanowerze, który pewnego dnia wyznał mu, „że przy oddawaniu kału robi też spermą” (s. 234). Sam Piotruś, który zgadza się odprawiać z panią Cin sadomasochistyczny rytuał, odgrywając przy tym rolę jej psa, pewnego razu śni, że jest muszlą klozetową, ,i pani Cin chętnie na mnie siada” (s. 242). Wariant tego snu opowiada lekarzowi: „pani Cin weszła do ubikacji, włożyła mnie do muszli. Usiadła" (s. 247) ${ }^{16}$. Zwłaszcza w kontekście erotyki sadomasochistycznej nie dziwi również, że klozet u Lipskiego naznaczony jest podwójnym wartościowaniem. Z jednej strony jest miejscem opresji. Ten aspekt zostaje, rzecz jasna, szczególnie mocno uwypuklony w Piotrusiu: główny protagonista dzień w dzień jest zamykany od zewnątrz w klozecie. Stosunkowo oczywista hipoteza, że postać, która go tam zamyka, to figura matczyna, że - innymi słowy - pani Cin przynajmniej częściowo i w jakimś sensie jest symboliczną matką Piotrusia, który mocą upokarzającego zdrobnienia utrzymywany jest w pozycji dziecka, znajduje pośrednie potwierdzenie w opowiadaniu Sarni braciszek, gdzie okrutna matka "wsadza" przerażonego chłopca "do ubikacji, w której trzymała też kury” (s. 271). W tym samym opowiadaniu zresztą pojawia się wzmianka o niejakiej pani Rosenzweig, która tak jak sam Lipski, cierpi na prawostronny paraliż, "«bo w klozecie za dużo gniotła», wytężała się za bardzo" (s. 271)".

16 Warto przypomnieć, że Zygmunt Freud łączył sadomasochizm z erotyzmem analnym, mówiąc o pregenitalnej fazie sadystyczno-analnej, na której nasza psychika może się utrwalić i do której w sytuacjach konfliktowych może dokonywać regresji. Zob. np. S. Freud Trzy rozprawy z teorii seksualnej, w: tegoż Życie seksualne, przeł. R. Reszke, KR, Warszawa 1999, s. 88-89. Jean Laplanche i Jean-Bertrand Pontalis komentują: „Jak należy rozumieć powiązanie między sadyzmem i erotyzmem analnym? Sadyzm, ze swej natury dwubiegunowy - dąży do pozostających w sprzeczności celów: zniszczenia obiektu i zachowania go dzięki panowaniu nad nim - znajdowałby więc szczególne odniesienie w dwufazowym funkcjonowaniu zwieracza i odbytu (wydalanie - zatrzymywanie) i kontroli nad nim". J. Laplanche, J.-B. Pontalis Słownik psychoanalizy, przeł. E. Modzelewska, E. Wojciechowska, WSiP, Warszawa 1996, s. 66.

Rosenzweig to oczywiście dość pospolite żydowskie nazwisko. Trudno jednak w tym kontekście nie pomyśleć o Franzu Rosenzweigu, który także cierpiał na paraliż (dokładniej: stwardnienie zanikowe boczne). Nie wiem, czy Lipski znał jego pisma, nie mógł jednak raczej o nim nie wiedzieć, skoro przez jakiś czas pozostawał w kontakcie z Martinem Buberem, który przyjaźnił się z autorem Gwiazdy zbawienia. Być może ze względu na chorobę jego własny los kojarzył się Lipskiemu z losem filozofa, być może też jednak postać sparaliżowanej pani Rosenzweig w opowiadaniu poświęconym Zagładzie ma stanowić ogólniejszą figurę kondycji żydowskiego 
Z drugiej strony jednak, w Niespokojnych klozet opisany jest jako ostateczne schronienie, z którego główny protagonista, Emil, zwykł był korzystać w dzieciństwie, kryjąc się tam przed matką i oczekując powrotu łagodniejszego ojca (s. 49 i 57). Dorosły Emil nosi tę zamkniętą przestrzeń w swoim wnętrzu: „Uciekał przed niepokojem do mrocznej królikarni ojca, do klozetu - żyjącego w nim zawsze schronienia dzieciństwa" (s. 117). Także jako strefa opresji klozet może być w ten sposób uwewnętrzniony: pod koniec wizyty w Jerozolimie Piotruś mówi do swojej ukochanej, Batii: „Zaczął mnie w końcu ugniatać mój klozet. [...] Ten, który na mnie czeka" (s. 242). Klozet jest tu więc równocześnie czymś zewnętrznym i wewnętrznym, zawierającym i zawartym: od wewnętrz "gniecie" Piotrusia, by ten powrócił do jego zewnętrznej postaci i ponownie się w nim zamknął. Ostatecznie, w finałowym rozdziale powieści, te dwie postacie spotykają się i sparaliżowany Piotruś - „zamurowany we własnym ciele (jak mniszki zamurowywano)" (s. 256), zamknięty na klucz w sobie samym - staje się w istocie $\mathrm{z}$ owym kiblem tożsamy ${ }^{\mathbf{1 8}}$. Wcześniej jednak jeszcze, w dialektycznej opozycji do tych obrazów radykalnego uwięzienia, w niezwykłej halucynacji Piotrusia klozet w obcym domu staje się cudownym portalem ku otwartej przestrzeni i utopijnej fantazji rozgrywającej się w utraconej, a w istocie nigdy niewidzianej wsi na polskich Kresach - z której wszelako Piotruś zostaje wypluty na hałaśliwą ulicę Tel Awiwu (s. 251-254).

świata: w swoim głównym dziele Franz Rosenzweig projektował odnowę żydowskiego życia zbiorowego regulowanego praktyką rytualną; paraliż, zanim jeszcze doprowadził go do śmierci w roku 1929, dosłownie i okrutnie odciął mu drogę do tego - kluczowego w jego rozumieniu wymiaru żydowskiego życia. Jeśli chodzi o relacje Lipskiego z Buberem zob. L. Lipski Paryż ze złota..., s. 170 i 179.

18 Jako człowiek-kibel Piotruś jest też pojemnikiem, który wypełnia babeliczna mieszanina wspomnień. Gdy podczas transakcji na targu pani Cin pyta go, co robił „wczoraj, przedwczoraj”, Piotruś zaczyna wyrzucać z siebie chaotyczne, potworne wspomnienia o ludzkim nieszczęściu. "Wtedy zrozumiałem, że za dużo pamiętam" (s. 203). Fekalny charakter wspomnień zostaje nazwany po imieniu w pierwszym rozdziale Niespokojnych: „Jem przeszłość, jak gdybym jadł własny kał, przeżuwam ją ciągle na nowo i znów od początku" (s. 29). Przy okazji warto wspomnieć, że fraza, którą posługuje się pani Cin, „wczoraj, przedwczoraj”, to hebraizm: idiom tmol szilszom, dosłownie "wczoraj, przedwczoraj", oznacza po hebrajsku "dopiero co, przed chwilą". Tak się zresztą składa, że jest to również tytuł wydanej w roku 1945 wielkiej powieści S.J. Agnona. Lipski, który nie czytał po hebrajsku, nie mógł znać tej powieści, być może jednak przynajmniej po części by się w niej rozpoznał: opowiada ona o porażce naiwnego chłopaka, który - mimo początkowego animuszu i syjonistycznych ideałów - nie potrafi odnaleźć się w palestyńskiej rzeczywistości pierwszej dekady XX wieku. Por. S.Y. Agnon Only Yesterday, trans. by B. Harshav, Princeton University Press, Princeton 2000. 
Zarazem klozet jest też u Lipskiego strefą heretyckiej religijności. Mały Emil, bohater Niespokojnych, ogląda na ścianach swojego toaletowego refugium „magiczne znaki i obrazy, którymi, jak ludzie pierwotni jaskinie, pokrywał klozet” (s. 49). Owo schronienie jest dla niego „miejscem tradycyjnym, rytualnym i samotnym" (s. 57). A udręczeni lokatorzy nie tylko „we wszystkich językach" błagają Piotrusia, by wyszedł z klozetu, lecz także klękają pod drzwiami i zaklinają go "na wszystkie świętości, nawet buddyjskie” (s. 211). W pewnym miejscu inwalida wspomina też mimochodem: „miałem okazję słyszeć w klozecie modlitwy żydowskie" (s. 225). Oczywiście idzie najpewniej o to, że zamknięty w klozecie Piotruś słyszy modlitwy odmawiane w mieszkaniach czy sąsiednich domach. Przez samo usytuowanie słuchacza modlitwy te zostają wszakże zbezczeszczone, co gorsza zaś, dwuznaczna składnia pozwala wręcz odczytać to zdanie jako doniesienie o modlitwach, które rozbrzmiewają wyłącznie wewnątrz klozetu. Jeszcze sprytniej skonstruowany wydaje się w tym kontekście fragment, w którym Piotruś wspomina ogłoszenia z gazetki w amerykańskim obozie w Iranie:

Nabożeństwo katolickie o zwykłej porze. Fryzjer przyjmuje 24 godziny na dobę. Zwycięstwo sowieckie pod X. Klozet drugiej klasy został otwarty koło kantyny głównej. Nabożeństwo żydowskie odprawi kapitan Rubin. (s. 238)

Mocą przyległości nowy klozet staje się albo przestrzenią, w której kapitan Rubin ma odprawić żydowskie nabożeństwo, albo zgoła domem modlitwy jakiejś nowej, fekalnej religii naszych czasów, która będzie rywalizowała z judaizmem i katolicyzmem. Istotnie, w świecie Lipskiego klozet stanowi nie tylko otchłanne centrum wielkiego, babelicznego pomieszania, owej epoki, która - wedle słów narratora - „wiruje jak bąk, w jakimś dziwnym nie na serio" (s. 213). Jest też dziwną, heretycką, nieświętą Świątynią, Najnieświętszym z Nieświętych, które - rzecz charakterystyczna - usytuowane jest nie w Jerozolimie, lecz obok niej, w przemieszczeniu, i jako takie przemieszczone centrum rozbitego świata nieodparcie przyzywa bohatera, by powrócił z Jerozolimy i ponownie pogrążył się w gnoju.

Komicznie-upiorna, matczyna kapłanka tej Świątyni, pani Cin, wyposaża Piotrusia w pierwszy tom encyklopedii, tak że miejsce to staje się parodystycznym centrum wszelkiej wiedzy. Ponieważ jednak w tym świecie cała encyklopedyczna wiedza jest bezużyteczna, Piotruś nawet nie tyka tej książki. Pani Cin zapewnia, że i ona blokowałaby kibel w ciągu dnia - jej zdaniem taka 
blokada jest „jedyną drogą" (s. 206) - lecz, rzecz całkiem już paradna, a zarazem nader istotna, niestety nie ma czasu, ponieważ uczęszcza na „posiedzenia Badaczy Pisma Świętego" (s. 206). Ona sama jest też heretycką teolożką albo też Piotruś w swoich halucynacjach postrzega ją jako kogoś takiego. Oto bowiem jak brzmi jej apokryficzna wersja biblijnej opowieści o stworzeniu człowieka i/lub kabalistycznej legendy o Golemie - zgodnie z podtytułem Piotruś to "apokryf" - wersja jak najbardziej stosowna w babelicznym świecie, którego centrum stanowi klozet: „Kał nie jest martwy. On jest początkiem wszystkiego. Jest ciepły i miękki. Z niego można jeszcze, jeszcze wszystko zrobić" (s. 214). Teologia ta może być szalona i przesycona jadowitym sarkazmem, lecz w powtórzonym słowie „jeszcze” słychać też przecież najgłębszą rozpacz. W świecie rozbitym przez Zagładę Paul Celan zaproponował swoją wersję psalmu, rozpoczynającą się od znanych, celowo dwuznacznych słów: „Nikogo, kto by nas na powrót ulepił z gliny i z ziemi, / nikogo, kto by mową ożywił nasz proch. / Nikogo. // Ciebie, Nikogo, chwalimy"19. Lipski nie flirtuje z teologią negatywną: miast szacować stopień nieobecności sacrum, zmierza w przeciwnym kierunku, w stronę bluźnierczego, fekalnego apokryfu. Gdyby jednak miał sparodiować dykcję Celana, powiedziałby może: „Nikogo, kto by nas na powrót ulepił z gówna i z kału, / nikogo, kto by mową ożywił nasz gnój. / Nikogo". O chwalbie raczej by nie wspominał.

Otóż tę właśnie nieświętą świątynię zamieszkuje Piotruś, człowiek zniekształcony, zamurowany we własnym ciele. Ingeborg Bachmann zwraca uwagę, że bohater powieści Lipskiego jest odległym kuzynem różnych włóczęgów, których znamy z twórczości Samuela Becketta ${ }^{20}$. Myśląc o zniekształconym ciele i zamkniętym pokoju, moglibyśmy też wspomnieć biednego Gregora Samsę. I tym razem zresztą w sukurs przyszedłby nam może Walter Benjamin, który zastanawiając się nad ową „ daleką obczyzną", charakterystyczną dla świata i wrażliwości Kafki, zauważa, że ostateczną i najważniejszą konsekwencją zamieszkiwania tej przestrzeni alienacji jest wyobcowanie od samego siebie. Jego komentarz w tej sprawie wydaje się szczególnie uderzający, gdy czytamy go w kontekście powieści Lipskiego:

19

P. Celan Psalm, przeł. J. Ekier, „Literatura na Świecie” 1997 nr 1-2, s. 254.

I. Bachmann Ein Maximum an Exil..., s. 449. Zob. np. S. Beckett Pierwsza miłość i Wypędzony, w: tegoż no właśnie co, przeł. A. Libera, PIW, Warszawa 2010, s. 259-281 i 283-298. Także bohaterowie Becketta nierzadko koncentrują się na sferze analnej i przesiadują w klozecie. Zob. tamże, s. 264 i 289 (w tym drugim przypadku mowa jest o związku między pokrzywionym krokiem bohatera a zaburzoną defekacją). W Pierwszej miłości mowa jest też o „archaicznych ekskrementach historii" (s. 269). 
Albowiem dzisiejszy człowiek żyje w swoim ciele tak, jak K. w wiosce pod górą zamkową; ciało wymyka mu się, jest wobec niego wrogie. Może się zdarzyć, że człowiek obudzi się pewnego ranka i odkryje, że przemienił się w robaka. Obcość - jego własna obcość - stała się jego panem. ${ }^{21}$

Wreszcie, mając na uwadze figurę zamurowania we własnym ciele ${ }^{\mathbf{2 2}}$, moglibyśmy też pomyśleć o protagonistach biało-szarych opowiadań Brunona Schulza, które opisują dialektyczny rewers, smutną podszewkę jego kolorowego świata: o emerycie z opowiadania Samotność, zamurowanym w pokoju swego dzieciństwa, o Edziu, człowieku o bezwładnych nogach, który jest wprawdzie dorosłym mężczyzną, niczym dziecko jednak pozostaje całkowicie we władzy upokarzających i maltretujących go rodziców, wreszcie o niepełnosprawnym umysłowo obywatelu imieniem Dodo, w którego ciele czy duszy nocami jęczy ktoś (jak mówi sam Dodo) „zamurowany”:

Nieżyte życie męczyło się, dręczyło w rozpaczy, kręciło się jak kot w klatce. W ciele Doda, w tym ciele półgłówka ktoś starzał się bez przeżyć, ktoś dojrzewał do śmierci bez okruszyny treści. ${ }^{23}$

W. Benjamin Franz Kafka, s. 242.

Jeśli chodzi o pokrewne próby uchwycenia kondycji człowieka dotkniętego cielesnym (ale i duchowym) paraliżem, warto także zwrócić uwagę na dwa sugestywne "egotyki". Pierwszy, zatytułowany Jeden ruch, brzmi następująco: „Daję się pożerać czasowi, jak ptak, który ujrzał węża, powoli, nieuchronnie / i nie mogę wykonać ruchu”. Drugi, zatytułowany /a, łączy tę kondycję z uniwersum fekaliów: „Byłem posągiem w zaniedbanej części parku i dzieci bawiły się koło mnie / i gołębie kakały mi na głowę", L. Lipski, Paryż ze złota..., s. 61 i 63.

B. Schulz Dodo, w: tegoż Opowiadania. Wybór esejów i listów, opr. J. Jarzębski, Ossolineum, Wrocław 1989, s. 284 (wzmianka o „zamurowanym” na s. 285). Opowiadania Edzio i Samotność, tamże, odpowiednio, s. 285-293 i 310-312. W publicznym wystąpieniu Jerzy Jarzębski zwrócił uwagę, że po części ze względu na doświadczenie egzystencjalne, po części ze względu na styl prozatorski pisarstwo Lipskiego można również łączyć z twórczością pisarza, którego skądinąd dość powszechnie (a zdaniem Jarzębskiego niezbyt trafnie) kojarzy się z Schulzem. Pisarzem tym byłby rumuńsko-żydowski prozaik Max Blecher, który ze względu na gruźlicę kręgosłupa spędzał długie miesiące w gipsowym pancerzu. Zob. M. Blecher Zabliźnione serca, przeł. T. Klimkowski, W.A.B., Warszawa 2013 i tegoż Zdarzenia w bliskiej nierzeczywistości, przeł. J. Kornaś-Warwas, Pogranicze, Sejny 2013. Interesujący wydaje się w tym kontekście zwłaszcza pierwszy rozdział tej drugiej książki: narrator medytuje tu nad swoją samotnością w pokoju, który wyprawia dziwne halucynacyjne harce, spokrewnione być może z deformacjami i „torsjami", jakie targają pokojem Piotrusia (s. 244). Przynajmniej w przypadku Lipskiego wydaje się, że owe torsje mają potrójny sens. Po pierwsze, zaświadczają oczywiście o tym, że udręczony bohater z coraz większym trudem odróżnia urojenia od rzeczywistości. Po drugie, przedmioty 
Jednak bez względu na te i inne powinowactwa nie sposób zataić faktu, że sam Piotruś charakteryzowany jest w tonacji heretycko-religijnej, a ściślej: mesjańskiej. Nie uszło to oczywiście uwagi komentatorów powieści Lipskiego ${ }^{24}$. I tak, wskazuje się, że akcja powieści rozpoczyna się wiosną, a więc w okolicach zarówno Pesach, jak i Wielkanocy; że upokarzający szyld nad głową Piotrusia może być aluzją do ironicznego napisu „król żydowski” na krzyżu Jezusa; że w czwartym rozdziale powieści pojawia się osobnik na osiołku, na którym wszak powinien wędrować mesjasz - choć, zauważmy, osobnikiem tym nie jest wcale Piotruś, lecz pewien Arab, przed którym tłum rozstępuje się niczym „morze” (s. 203). Trudno też przeoczyć okoliczność, że córeczka sąsiadów (ta, która stopniowo traci polszczyznę na rzecz hebrajskiego) wywrzaskuje nad głową Piotrusia „Da-wid, Da-wid, król Israeee-la” (s. 227), a potem po hebrajsku: „Da-wid, Da-wid, me-lech Israel” (s. 229) od Dawida zaś wywodzi się oczywiście mesjański lineaż ${ }^{25}$. Mamy tu zatem do czynienia z szeregiem mesjańskich tropów, które bądź to (jak napis na szyldzie) mają charakter chrześcijański, bądź to (jak osiołek czy lineaż Dawidowy) mają charakter judaistyczny, lecz zostały także przyswojone przez tradycję chrześcijańską. Całkiem otwarcie jako figurę chrystologiczną przedstawia Piotrusia doktor Siegbert, lekarz, do którego inwalida udaje się pod koniec powieści. Także i ten fragment z oczywistych względów przykuł uwagę komentatorów. Siegbert mówi m.in.: „Każdy z nas chodzi do ubikacji. I pan

ożywają tu poniekąd w reakcji na narastające znieruchomienie bohatera i owo znieruchomienie dodatkowo uwypuklają, osaczając go swoją napastliwą aktywnością. Po trzecie, oszalały pokój triumfalnie "wyrzyguje" Piotrusia, który tym samym nie może znaleźć sobie miejsca nigdzie poza klozetem.

Zob. np. S.J. Żurek Podwójny Mesjasz. O możliwościach interpretacyjnych „Piotrusia” Leo Lipskiego w kontekście tradycji i teologii żydowskiej, "Podteksty” 2008 nr 1 (23.11.2016). We wstępnych rozpoznaniach Żurek podąża po części za Hanną Gosk, autorką pierwszej książki o Lipskim. Por. H. Gosk Jesteś sam na swojej drodze, Świat Literacki, Izabelin 1998.

Ponieważ Piotruś słyszy to wołanie z wnętrza klozetu, można się zastanawiać, czy heretyk Lipski nie chciał, byśmy w słowach dziewczynki wyodrębnili słówko "sra". Jeśli wziąć pod uwagę, że cząstka "el" oznacza Boga, wówczas moglibyśmy dojść do wniosku, że w swej pomieszanej polsko-hebrajskiej mowie dziewczynka obwieszcza światu, że Bóg robi kupę na swój babeliczny świat. Ten wulgarny żart jak najbardziej pasowałby do fekalnej teologii Lipskiego. Antoni Zając (UMFK) zwrócił mi też uwagę, że to właśnie od tej dziewczynki podchodzi komiczno-pokraczna fraza "zrobić się na pies" (s. 209), za pomocą której Piotruś opisuje potem sadomasochistyczne praktyki, w jakie wdaje się z panią Cin. To koślawe wyrażenie stanowi zatem nazwę heretyckiego rytuału upokorzonego króla Izraela. 
sobie tam urządził prywatną golgotę". A dalej, komentując masochistyczny sen Piotrusia z panią Cin:

Nie szkodzi, pan ma cierpieć. Och, biedny Piotruś. Za nas wszystkich. Zbawienne sny. Zbawienny klozet. [...] Gdy pan odczuwa seks przez ból... To jeszcze nic. Takich jest miliony. Gdy pan odczuwa ból przez seks... I gdzie pan nie odczuwa bólu? O, wielki Piotrusiu. Czyżby pan cierpiał za całe nieudane pokolenie? Nie wiem, na Boga Żywego, nie wiem... (s. 247)

Wydaje się jednak, że wszystkich tych odniesień, w szczególności zaś owego chrystologicznego kazania doktora Siegberta, nie można czytać bezkrytycznie. Przede wszystkim wiedza, którą dysponuje lekarz (np. o związku Piotrusia z Batią), może wskazywać, że i w tym wypadku chodzi raczej o halucynacje głównego protagonisty powieści. Nawet jednak jeśli odrzucimy tę hipotezę jako ostatecznie mało istotną, a także przymkniemy oko na fakt, że na wcześniejszym etapie fabuły doktor współpracował z panią Cin, gdy ta usiłowała przełamać opór strajkującego Piotrusia, nie sposób pominąć okoliczności, że choć długi wywód lekarza jest pod wieloma względami poruszający, jest też zarazem tekstem całkowicie obłąkańczym, niedorzecznym i po prostu bardzo śmiesznym. Być może więc mamy raczej do czynienia z sarkastyczną parodią teologii niż z jej najbardziej nawet heretycką odmianą. Jeśli chcielibyśmy mimo wszystko potraktować tę teologię poważnie, musielibyśmy uwzględnić wszystkie jej elementy, a także rozchwierutaną formę, w jakiej została przedstawiona. Przejawem naiwności byłoby przyjęcie, że Siegbert kreśli tutaj spójną, pozytywną chrystologię z klozetem w roli krzyża, teologię, zgodnie z którą Piotruś jako Chrystus mocą swojego masochistycznego upokorzenia zbawi upadły świat tonący w ekskrementach. Jeśli bowiem obłąkany doktor szepcze pod koniec swojego wywodu: „Przecież Bóg, sam Bóg jest schizofrenikiem" (s. 249), to trudno uznać, by w rozpękniętym, babelicznym świecie, w którym schizofrenia dotknęła samego Stwórcy, możliwe było sprawne funkcjonowanie machiny zbawienia. Popękany, chwilami groteskowy, a chwilami przejmujący dyskurs doktora może być rzeczywiście teologią tego świata, ale właśnie teologią z konieczności popękaną, rozbitą wewnętrznie przez niedorzeczność.

Co bodaj ważniejsze, finał powieści nie potwierdza przekonania, jakoby Lipski miałby tutaj forsować chrystologiczną teologię zbawienia przez upokorzenie. Owszem, imię głównego bohatera - jeśli pominąć upupiające 
zdrobnienie - wydaje się odsyłać do św. Piotra-Opoki. Jeśli jednak Piotruś ma przemienić się w skałę, to stanie się to u kresu jego życia, u progu ostatecznej anihilacji, a na tym fundamencie nie wzniesie się raczej żadnego Kościoła. Jak czytamy w ostatnim zdaniu powieści: „I wtedy wejdą zwierzęta do twojego pokoju i siądą na tobie spokojnie, jak na kamieniu i ziemi” (s. 256). Co więcej, we wcześniejszym fragmencie czytamy: „Pieją koguty. Nie wiem, jak Jezus mógł sobie z nimi poradzić. «Trzeci kur» jest całkowicie dowolnym pojęciem. Pieją całą noc" (s. 208). Fragment ten wskazuje, że imię głównego protagonisty odsyła raczej do bezgruncia Piotrowej zdrady, po której w tym zaburzonym świecie permanentnego koguciego piania nie następuje żadna skrucha. Piotruś to apokryf, a Piotruś to wysoce heretycki mesjasz. Lecz jeśli nawet jest on - w jakimś sensie - królem Izraela, nie zbawi ani siebie, ani nas poprzez swoje upokorzenie. Kim zatem jest i co takiego robi w świecie babelicznego pomieszania?

Otóż warto zwrócić uwagę, że jeden z ostatnich rozdziałów powieści Niespokojni - dokładniej: rozdział trzeci od końca - opatrzony jest nader szczególnym mottem. Brzmi ono następująco: „Błogosławiony ten, który przyzwolił na wszystko złe... Signor Santo Barochiah" (s. 137). Nie wiem, ile Lipski wiedział o antynomistycznych tradycjach szabtaizmu i frankizmu, lecz owo motto wskazuje, że coś wiedział ${ }^{26}$. Signor Santo Barochiah, czyli Baruchia Russo, był drugim pretendentem do mesjańskiego tronu po Szabtaju Cwi, XVII-wiecznym mesjaszu-apostacie, a przed Jakubem Frankiem. Owo dictum, popularne we frankistowskich kręgach, istotnie mu przypisywano. Co więcej, sam rozdział opatrzony tym mottem, a zatytułowany Zemsta, poświęcony jest - nader adekwatnie - opisowi aktu seksualnego między Emilem i jego ukochaną, Ewą, aktowi, który zgodnie z sugestią samej Ewy odbywa się w jej rodzinnym domu i jawnie przedstawiony jest jako „obrządek zhańbienia” (s. 141). Gdy bohaterowie się kochają, światła pozostają zapalone, a młodsza siostra Ewy podgląda przez szparę w okiennicach, przez co rzecz dodatkowo nabiera posmaku antynomistycznego rytuału, pokrewnego obrzędom seksualnej transgresji odprawianym przez Jakuba Franka i jego otoczenie.

Można by zatem pójść za tą wskazówką i odnieść ją do drugiej powieści Lipskiego, w której pisarz otwarcie podejmuje mesjańskie tropy. Innymi

26 Na temat szabtaizmu i frankizmu zob. G. Scholem Mistycyzm żydowski i jego główne kierunki, przeł. I. Kania, Czytelnik, Warszawa 1997, s. 352-394 oraz P. Maciejko Wieloplemienny tłum. Jakub Franki ruch frankistowski (1755-1816), przeł. .. Chmielewski, Wydawnictwo w Podwórku, Gdańsk 2014. 
słowy, można by podjąć próbę odczytania mesjanizmu Piotrusia przez pryzmat antynomistycznej tradycji frankistowskiej, przeseksualizowanej postaci samego Franka i jego wulgarno-bluźnierczych żartów z tradycji ${ }^{27}$. Podobnie jak u Franka, chrystologia byłaby tu tylko pozorem i przykrywką: szłoby w istocie o antynomistyczny, żydowski mesjanizm, zabójczy zarówno dla chrześcijaństwa, jak i dla ortodoksyjnego judaizmu. Także element analno-fekalny można by odnaleźć we frankistowskich pismach, a mianowicie - całkiem adekwatnie - w kontekście „dziwnych uczynków” mesjasza, który musi pohańbić dawne prawa, by przywieść świat do zbawienia. We frankistowskiej Księdze stów Pańskich czytamy bowiem:

Przyszedłem raz do bożnicy w Salonice, gdzie okole 1200 gospodarzy znajdowało się, gdy już tamecznym obrzędem jeden ze szkolników miał przywołać, żeby ten a ten postąpił do czytania Praw Mojżeszowych na górę, zawołałem mocnym głosem: Niechaj mi się żaden tu nie doważy wejść na tę ambonę, bo go tu na miejscu położę. Wszyscy zdziwieni poczęli krzyczeć: Jak to ty masz bronić! Tak ja, powtórnie toż zawoławszy, porwałem pulpit i krzyknąłem, że pierwszego co się iść waży, tym zamorduję, a potem wziąwszy te Prawa Mojżeszowe położyłem na gołej ziemi i spuściwszy spodnie, usiadłem gołym zadkiem na nich, a wszyscy Żydzi nic nie wskórawszy wyjść musieli. ${ }^{28}$

A jednak już sam ten fragment wskazuje oczywistą, zasadniczą różnicę między Frankiem a Piotrusiem: Frank to mesjasz radosny, aktywny i gwałtowny (by nie rzec po prostu: chamski); Piotruś, choć arcycielesny i arcyseksualny, jak sam Frank, to człowiek cierpiący, niemal całkowicie bierny i głęboko pogrążony w mrocznym świecie perwersji. Jeśli jest frankistą, to praktykuje frankizm pasywny. Nie siada gołym tyłkiem na świętej księdze, lecz samemu daje się zamknąć w klozecie, w istnym anus mundi. Talmud Babiloński mówi: „Kto drwi ze słów mędrców, ten kończy

27 Nie powołując się na Niespokojnych, z frankizmem wiąże Piotrusia Sławomir Żurek, ma jednak przy tym na uwadze bodaj wyłącznie przeświadczenie Franka, że prawdziwy mesjasz powinien być kobietą, przeświadczenie, które przywódca ruchu odnosił do swojej córki Ewy (!).Zdaniem Żurka w uniwersum Lipskiego tę funkcję miałaby pełnić Batia, ta interpretacja wydaje mi się jednak wymuszona i schematyczna, ignoruje bowiem przebieg fabuły powieści i rolę, jaką odgrywa w niej Batia - aż po mroczny finał całej historii. 
we wrzących ekskrementach"29. Piotruś, bohater, a zarazem narrator apokryficznej opowieści, która może być potraktowana jako drwina z samego Pisma, ostatecznie godzi się z tym talmudycznym werdyktem jako nieuchronnym. Zstępuje na dno szamba. W związku z tym ktoś mógłby zauważyć, że więcej niż z Jakuba Franka ma bodaj z samego Szabtaja Cwi w ujęciu jego proroka, Natana z Gazy. Wedle Natana bowiem Szabtaj, człowiek cierpiący prawdopodobnie na chorobę dwubiegunową, jako mesjasz zstępuje do otchłani i wydany jest na pastwę węży czy smoków, w czym przypomina zresztą biblijnego Hioba, który znalazł się we władzy skorup $\mathrm{zła}^{30}$. Jako cieleśnik przepełniony libidinalną energią byłby więc Piotruś krewnym Jakuba Franka, jako podobny Hiobowi cierpiętnik pogrążony w otchłani - krewnym umęczonego Szabtaja. Także i ten manewr interpretacyjny natrafiłby zaraz na swoje granice. Inaczej bowiem niż Szabtaj, Piotruś nie pokonuje w otchłani smoka pradawnego. Nawet jeśli wedle doktora Siegberta Piotruś w swoich masochistycznych snach pokonuje panią Cin (s. 247), to także w tym wypadku ani samoobalająca się teologia schizofrenicznego Boga, ani straszny finał powieści nie pozwalają wierzyć

29 TB Gittin 56b-57a oraz TB Eruwin 21b, cyt za: Y. Furstenberg The Midrash of Jesus and the Bavli's Counter-Gospel, "Jewish Studies Quarterly" 2015 No. 4, s. 314-315. Furstenberg wskazuje, że w traktacie Gittin zasada ta służy uzasadnieniu opłakanego losu Jezusa, fałszywego mesjasza, który miał drwić z żydowskich mędrców: w piekle Jezus kończy właśnie w gotującym się kale. W kontekście powieści Lipskiego nader intrygujące wydaje się także rozumowanie Furstenberga, który w świetle tego passusu interpretuje inny, dość zagadkowy fragment Talmudu, gdzie Jezus dowodzi, że pieniądze z prostytucji, których nie można przekazać na Świątynię, można było wszakże spożytkować na budowę klozetu dla Najwyższego Kapłana. Wywód Jezusa spotyka się z aprobatą rabiego Eliezera. Furstenberg przekonuje, że historia ta ma w istocie zdyskredytować Jezusa. W jego opinii rabi Eliezer chytrze aprobuje ów wywód, ponieważ Jezus bezwiednie mówi tutaj o sobie: zrodzony z prostytutki (wedle Talmudu Maria była kurwą) skończę w ekskrementach. W interpretacji Furstenberga „klozet Najwyższego Kapłana” to ów wrzący kał, który czeka w piekle na każdego, kto drwi ze słów mędrców, w szczególności zaś na Jezusa. O tych fekalnych rewelacjach opowiedział mi po raz pierwszy Elad Lapidot (UMFK), który udostępnił mi także egzemplarz artykułu Furstenberga - za co niniejszym składam mu serdeczne podziękowania.

Zob. G. Scholem Mistycyzm żydowski..., s. 362-363. Trop ten jest atrakcyjny także pod tym względem, że pozwala skojarzyć samego Natana z doktorem Siegbertem. Według Scholema Szabtaj ogłosił się mesjaszem właśnie pod wpływem Natana, u którego zjawił się wszakże, szukając pomocy w swym cierpieniu. „Uważam, że to najważniejszy moment w dziejach Sabbataja Cwi. Kiedy bowiem rozeszły się pogłoski o «przebudzeniu» Natana, przyszedł do niego Sabbataj Cwi, choć nie jako Mesjasz czy też na mocy jakiejś tajemniczej zmowy, lecz po to, by «zapewnić swojej duszy spokój». Powiedzmy wprost: Sabbataj Cwi przyszedł jako pacjent do lekarza dusz" (tamże, s. 361; wyróż. - A.L.). 
w skuteczność tego przezwyciężenia. Ale jeśli tak, to - raz jeszcze - co takiego robi Piotruś, jeśli nie robi właściwie nic? Na czym miałby polegać jego bierny frankizm, jeśli w ogóle można o czymś takim mówić?

Świat Niespokojnych, powieści, której akcja rozgrywa się w przedwojennej Polsce, to zaburzony kosmos wewnętrznego niepokoju, który w symbolistycznym duchu wyraża się w niepokoju zewnętrznym („Czarna burza stoi na zachodzie", s. 68), uniwersum pełne smutku i przeczuć nadchodzącej śmierci, opisane czasem z ostrością i bezwzględnością dojrzałej prozy Lipskiego, częściej jednak w tonacji nieznośnej, dusznej młodopolszczyzny raz po raz osuwającej się w mimowolną śmieszność („Była szczytem kobiecości, jej szczytem i zarazem otchłanią. Bez dna"; s. 94). Jest to także świat, gdzie - raczej w duchu dekadenckiego modernizmu niż łobuzerskiego frankizmu transgresyjna ekstaza seksualna splata się z popędem śmierci: przedostatni rozdział powieści, który następuje zaraz po rozdziale opatrzonym mottem z Baruchii Russo, opisuje samobójstwo głównej bohaterki ${ }^{31}$. Tymczasem świat Piotrusia to rzeczywistość po katastrofie czy raczej uniwersum katastrofy permanentnej, kosmos gwałtownie roztrzaskany, gdzie nawet Bóg jest schizofrenikiem. To świat, który nie oczekuje śmierci, bowiem śmierć jest już za nim i w nim. Najczytelniej mówi o tym Lipski na samym początku opowiadania Waadi:

Zagęszczenie śmierci w kraju, który zamieszkuję, jest nieprawdopodobne. Ludzie, sami żywi, promieniują swoimi zmarłymi. Ludzie, nosiciele śmierci, jak kamyki rzucone na wodę rysują koła rozchodzące się, wpadające na siebie... (s. 191)

Jest to również świat, w którym nie ma już miejsca na chmurną acz patetyczną wiarę w splot miłości i śmierci. Relacje między tymi dwoma żywiołami są tu bardziej skomplikowane.

Zrazu wydaje się, że miłość - o ile istnieje - nie jest w uniwersum Piotrusia zakażona śmiercią i w tym sensie może wskazywać wyjście z bezwyjściowej sytuacji. Wspaniała, zaskakująca, mądra Batia jest - jak mówi Piotruś - "gwałtowną, nieświadomą zwolenniczką" bytu (s. 239). Batia to kibucowe

Splot miłości i śmierci nie ma istotnie wiele wspólnego z frankizmem, warto jednak odnotować, że i ten przedostatni rozdział został opatrzony znaczącym mottem: jest to mianowicie fragment wiersza Adama Mickiewicza, którego związki z frankizmem są tyleż niejasne, co niewątpliwe. W całej powieści tylko te dwa rozdziały zostały wyposażone w motta. 
dziecko, istota zdeprawowana, wykorzystywana i wykorzystująca, brzydka, zgrabna, promieniująca siłą i witalnością, nieskończenie pociągająca („nawet zwierzęta były o nią zazdrosne", s. 231), nierzadko okrutna, często jednak zaskakująco czuła, także dla złachanego Piotrusia. „Może się odzwyczaisz od swojej choroby?”, pyta go. „To jest brzydkie przyzwyczajenie i kto wie, czy ty tego nie symulujesz" (s. 226). Za tymi słowami stoi tak wielka życiowa siła, niestrawiona jeszcze przez rozczarowania, że właściwie nie sposób przypisać ich naiwności. „Ach, zdechlaku ty, zdechlaku” (s. 229), mówi Batia do Piotrusia, zarzuca go na ramię i uwalnia z klozetu. Tak zaczynają się osobliwe wakacje Piotrusia i Batii, które nie mają w sobie nic z transgresji czy antynomistycznego rytuału: nieprawdopodobni kochankowie, inwalida i dziewczynka, są po prostu na gigancie. Relacja z tej wyprawy, przetykana okrutnymi bajkami Piotrusia, a także oszczędnymi, lecz nadzwyczaj precyzyjnymi opisami palestyńskiej i (we wspomnieniach Piotrusia) irańskiej przyrody, naznaczona jest uderzającym pięknem, które dzięki ostrości języka, jakim posługuje się Lipski, wolne jest od jakiegokolwiek sentymentalizmu. Na swój szczególny sposób Piotruś stara się tu przeżyć i napisać swoją Szir ha-Szirim, Pieśń nad Pieśniami, o miłości mocnej jak śmierć. Mógłby bodaj znaleźć sprzymierzeńca w osobie obłąkanego ojca Batii, który mieszka w łazience i pisze „szirim”, lecz - ku rozczarowaniu szalonego poety - Piotruś nie czyta po hebrajsku (s. 221).

Tak czy inaczej, ta ostatnia próba ucieczki kończy się nader bolesną porażką, przede wszystkim dlatego, że Piotrusia „ugniata” klozet. Ku własnemu zaskoczeniu Piotruś mówi: "Ja chcę do mojego klozetu” (s. 243). Od decyzji o powrocie nie odwodzi go nawet przyniesiona przez Batię „dobra nowina”, że pani Cin wyjeżdża. Piotruś ma dość „szwędaniny”, podczas której zawsze będzie się musiał dzielić Batią z innymi. Widząc, że dziewczyna pozwala się obściskiwać kolejnemu gachowi, inwalida mówi z goryczą: „Miłość przychodzi, miłość odchodzi” (s. 243). Na co Batia: „«To» [czyli ich seksualne zbliżenie] nie ma nic wspólnego z uczuciem. Poza tym nie miłość przechodzi, tylko my". Piotruś komentuje: „Rozwarta szczelina. Nareszcie coś z niej. Zagadkowego" (s. 244). Tak więc właśnie w chwili rozstania ochronny pancerz Batii na moment pęka i odsłania coś, co dziewczyna naprawdę myśli, czuje lub czym naprawdę jest. Tym jednak, co ukazuje się w owym pęknięciu, jest jej smutna wiedza o miłości, o otchłannej wyrwie między miłością a nami samymi smutna mądrość, w porównaniu z którą patetyczne frazesy o splocie miłości i śmierci wypadają doprawdy naiwnie. Franz Kafka miał kiedyś powiedzieć w rozmowie z Maksem Brodem, że jest „nieskończenie wiele nadziei - tylko 
nie dla nas"32. Parafraza tych słów, jaką mogłaby sformułować Batia, brzmiałaby: „Jest nieskończenie wiele miłości - tylko nie dla nas”.

Wraz z tym rozdzierającym finałem romansu-nieromansu z Batią - finałem przypieczętowanym jej zimnymi słowami: „Oddaj mi moje dziesięć piastrów" (s. 244) - kończy się pierwsza część powieści. Część druga - i ostatnia - jest osobliwie krótka, lecz w metodyczny i nader intensywny sposób dokumentuje pewien proces, który teraz na dobre uruchamia się w Piotrusiu. Gdy inwalida ześlizguje się z Jerozolimy z powrotem do telawiwskiego klozetu, gdy wymierzywszy przepaść między sobą a miłością, osuwa się ponownie w życie przestrzelone śmiercią, znajduje się - jak mówi mu doktor Siegbert - na samym dnie, ,a nawet głębiej” (s. 247), a bez niczyich podpowiedzi świetnie wie, że „dno jest straszliwsze od śmierci” (s. 219). Teraz, krok po kroku, rozpoznaje stopień swojego poniżenia. Tym samym, krok po kroku, zdobywa czarną gnozę - czarną, bo ta wiedza nie daje zbawienia. Odwiedza doktora Siegberta, który stawia mu swoją obłąkańczą diagnozę i wtajemnicza go w schizofreniczną naturę Boga. W utopijnej halucynacji próbuje wymknąć się poprzez klozet ku polskiej idylli, sen jednak ulatnia się, rzecz jasna, bez śladu. „Wtedy zdałem sobie sprawę, że nie mogę do tego świata dotrzeć. Ze zduszonym gardłem zawołałem do siebie: - Z głębokości wołam do Ciebie" (s. 255). Piotrusiowe De profundis brzmi może nazbyt teatralnie, warto jednak zwrócić uwagę, że skierowane jest „do siebie”. Czy Piotruś woła do siebie, bo nie ma już Nikogo innego? Zapewne. Czy woła do siebie, bo i do siebie już dotrzeć nie potrafi ? Tak sądzę. Lecz ostateczny poziom samowiedzy, ostateczną formę czarnej gnozy - która okazuje się wiedzą o własnej niepoznawalności - inwalida osiąga dopiero na samym końcu, gdy raz jeszcze odwiedza Batię. Dziewczyna właśnie pakuje się, by wyruszyć w wymarzoną podróż do Paryża. Piotruś jest wstrząśnięty, teraz bowiem nie ulega wątpliwości, że Batia ostatecznie znika z jego życia.

Czytamy:

Byłem lekko ogłuszony. Nie, nie cierpiałem. W znieczuleniu prawie wesoły. Zdawało mi się, że powinienem się bać, ale nie umiałem. Czułem, że czegoś nie rozumiem. Jakbym był oślepiony w pewnym punkcie. Usiłowałem nadaremnie przypomnieć sobie to, co zapomniałem. Ale byłem pewien, że coś tam było jeszcze. I nagle zrozumiałem, że tego nigdy nie

32 M. Brod Franz Kafka. Opowieść biograficzna, przeł. T. Zabłudowski, Czytelnik, Warszawa 1982, S. 103. 
zobaczę. To nie było do patrzenia ani do rozumienia. To była część śmierci. (s. 255)

Mądra Batia, która wbrew wszelkim przeczuciom chce wierzyć, że w Paryżu jej się powiedzie, widzi najwyraźniej, że Piotruś dotarł do tego mrocznego punktu w samym sobie. Dziewczyna blednie nagle i krzyczy do niego: „Idź już. Idź już" (s. 256). Wie, co mówi. Bowiem zniekształcone ciało Piotrusia, zamknięte w klozecie, zamurowane w sobie samym, jest ostateczną ofiarą $\mathrm{i}$ istotą tego strzaskanego świata. Piotruś uświadamia sobie teraz, że w jego żywym ciele jest coś, czego nie sposób zobaczyć: część śmierci, która w wyniku nieskończonej agonii - „Czy warto ryzykować życie dla wielu lat konania?" (s. 256) - będzie stopniowo przekształcać jego ciało w nieruchome, wiecznie umierające jądro ruchliwego chaosu, w centrum życia nieodwołalnie przestrzelonego śmiercią. Być może Piotruś jest - lub staje się w wyniku nieskończonego procesu - niczym więcej niż takim właśnie miejscem nieskończonej kondensacji rozpadu. Być może jednak sama ta kondycja czyni go czymś jeszcze.

Jakub Frank, mesjasz-chamidło, z całą furią i dowcipem atakował symboliczny porządek znaczeń i prawa swoim ciałem kipiącym od energii seksualnej. Pragnął w ten sposób rozedrzeć gęstą teksturę immanencji i utorować drogę ku transcendencji zbawienia. W rezultacie dla Franka to, co cielesne - w przeciwieństwie do tego, co tekstualne - paradoksalnie uzyskało mesjański, transcendentny sens. Piotruś nie umie i raczej nie chce wykonywać tak gwałtownych gestów. Cierpienie, które nadchodzi z zewnątrz, i cierpienie wywołane jego własnymi decyzjami mieszają się w jego losie tak, że nie sposób ich właściwie od siebie odróżnić. Piotruś niby strajkuje i stara się uciec ze swojej klozetowej golgoty, powraca tam jednak, wiedząc, że „to jedyna droga". Na koniec jest tym, czym był na początku - ciałem, które sprzedaje się niczym kawał mięsa na babelicznym szuku - tyle że teraz nieskończenie głębiej pogrąża się w rozpaczy i dotyka o wiele głębszej, czarnej samo(nie) wiedzy. A jednak to bierne, sepleniące, jąkające się, sparaliżowane ciało czyni coś z otaczającym je światem immanencji i właśnie ze względu na tę skuteczność - skuteczność niedziałania - Piotruś ostatecznie zasługuje na osobliwe miano biernego frankisty.

Owo niedziałanie ma charakter dwoisty lub też dwojakiego rodzaju są jego skutki. Po pierwsze, zniekształcone, a zarazem obsceniczne ciało Piotrusia wyznacza przeszkodę, która na heretycką modłę kwestionuje i rozrywa wszystko, co jeszcze pozostało z naszych planów wpisanych w ramy porządku 
symbolicznego, z naszych projektów budowy państwa, z naszych marzeń o wyjeździe do Jerozolimy czy Paryża ze złota ${ }^{33}$. Gdy ludzie - dzieci i dorośli - spotykają Piotrusia na ulicy, ogarnięci zgrozą odwracają od niego wzrok (s. 244), czują bowiem, że jego ciało wyznacza punkt rozpadu wszystkich znaczeń. Koguty pieją całą noc, Piotruś pozostaje więc permanentnym zdrajcą i zaprzańcem, który swoim biernym oporem rozbija wszystkie nasze przedsięwzięcia. Podobnie też jego chciana/niechciana koncentracja w ośrodkowym punkcie sfery analno-fekalnej to jego demaskatorski, pasywno-agresywny atak na wszystkie nasze marzenia o miłości, która wykraczałaby poza rozpacz i bezradność sadomasochizmu i która - ostatecznie - mogłaby się okazać równie mocna jak śmierć.

Po drugie jednak, jego bierne ciało robi coś jeszcze ważniejszego. Bądź co bądź, porządek symboliczny, który otacza Piotrusia, i tak jest już mniej lub bardziej strzaskany, nawet jeśli ludzie rozpaczliwie udają, że wciąż jeszcze można czytać gazety. Jednak nawet jeśli zerwiemy ideologiczne zasłony i zmierzymy się z rozpadem, tym, co umyka naszemu spojrzeniu, tym, co ginie w powszechnym tohu wa-wohu, jest pojedynczość cierpienia, która stanowi atom tego chaosu. I to ją właśnie przede wszystkim wydobywa bierny frankizm Piotrusia. Przeradzając się w nieporuszoną skałę, na której nie sposób wznieść żadnego Kościoła, Piotruś wstrzymuje powszechny wir i w paradokalnym geście niedziałania przerywa, rozbija powszechne rozbicie. Nie zbawia ani siebie, ani innych, nie przywraca ładu w akcie tikkun olam, naprawy świata, lecz - poprzez absolutną intensyfikację chaosu - swoim udręczonym ciałem zaznacza punkt pojedycznego cierpienia.

Ale: czy na pewno? Być może trafniej byłoby powiedzieć, że - pisząc Piotrusia - czyni to sam Lipski. To zaś prowadzi mnie na powrót ku recenzji, której nie zdołała napisać Ingeborg Bachmann. W szkicach do tego tekstu autorka Maliny zastanawia się, czy Piotruś jest „dobrą" książką. Zapewne - pisze - jest książką „nieudaną", niewątpliwie jednak jest książką „prawdziwą” czy wręcz

Pod tym względem Piotruś okazuje się krewnym Justine Frank, wyimaginowanej, belgijsko-żydowskiej surrealistki powołanej do życia przez izraelskiego artystę Roee'ego Rosena (jej imię to aluzja do dzieła markiza de Sade, nazwisko zaś - do założyciela ruchu frankistowskiego). W ramach oporu wobec zainicjowanej przez syjonistów przemiany hebrajszczyzny w mowę codzienną Justine Frank - zamiast w reakcyjnym geście starać się utrzymać sakralny charakter tego języka - zdecydowała się na bluźnierczo-subwersywną intensyfikację owej sekularyzacji. Stworzyła mianowicie własny, obsceniczny alfabet hebrajski, w którym litery po części składają się z penisów i szeroko rozłożonych kobiecych nóg. Zob. http://roeerosen.com/page/6 (24.11.2016). 
"oświeconą", która nie daje się umieścić w żadnych znanych kontekstach czy ramach $^{34}$. Bachmann narzeka trochę na niemiecki przekład, a także na samego Lipskiego, który w jej przekonaniu nadużywa zaimków nieokreślonych, obniżając tym samym poziom precyzji swojej prozy. Najbardziej podobają się jej dialogi oraz pojedyncze zdania, dzięki którym książka Lipskiego mimo wszystko „przekonuje”35. Wykazując się znacznym czytelniczym słuchem, który pozwala wybaczyć jej raczej nietrafne i cokolwiek protekcjonalne zarzuty pod adresem polskiego pisarza, jako przykład stylistycznego sukcesu wyłuskuje krótkie, zaskakujące zdanie, które wieńczy świetny opis telawiwskiego poranka, „pory przełomu”, gdy „nic się nie dzieje, lecz wszystko delikatnie drga”: „Maniacy kąpią się w morzu” (s. 255). Bachmann wskazuje wszakże jedną jeszcze, ważniejszą grupę zdań w powieści Lipskiego. W jej przekonaniu Piotruś to mianowicie jedna z nielicznych książek, w której zdarzają się zdania o takiej intensywności, zdania tak piękne i bolesne zarazem, że zmuszają czytelnika do przerwania lektury ${ }^{36}$. Bachmann podaje dwa przykłady takich zdań. Pierwszym jest fragment o nieustannym pianiu kogutów; drugim - ostatnie zdanie powieści. Bachmann nie wspomina o usytuowaniu tego drugiego zdania w tekście, być może starając się uniknąć wyśmienitego paradoksu, który właśnie sformułowała: to paradoks ostatniego zdania książki, które zmusza nas do przerwania lektury. Paradoks ten był chyba niezamierzony, ale Bachmann - mimowolnie - uchwyciła rzecz znakomicie. Ostatnie zdanie powieści Lipskiego - jedno z najwspanialszych i najbardziej wstrząsających zdań

34 I. Bachmann Ein Maximum an Exil..., s. 439 i 446. Mimo niejednoznacznego charakteru tej oceny Gisela Nittel dowodzi, że w dyskursie krytycznym Bachmann „prawdziwość” jest najwyższą pochwałą. Nittel zwraca też uwagę, że "prawdziwy apokryf” Lipskiego mógł wywrzeć pewien wpływ na prozę samej Bachmann: autorka przypomina mianowicie, że tytułowy bohater Maliny zostaje zaprezentowany czytelnikowi jako "autor Apokryfu, który jest już nie do nabycia w księgarniach i którego parę egzemplarzy sprzedano w końcu lat pięćdziesiątych" (I. Bachmann Malina, przeł. S. Błaut, Czytelnik, Warszawa 1975, s. 5). Gdybyśmy zechcieli pójść tym tropem, moglibyśmy dopatrzeć się śladu Piotrusiowego "zamurowania” w tajemniczym w-ściano-wstąpieniu, które na koniec powieści Bachmann staje się udziałem jej bezimiennej bohaterki: „Ale ściana się otwiera, jestem w ścianie, a Malina zobaczy tylko rysę, którą już dawno widzieliśmy. [...] A w ścianie jest coś, co nie może już krzyczeć, ale jednak krzyczy: Ivan!" (tamże, s. 427). Zob. G. Nittel "Es ist ein unglaublicher Betrug”. Ingeborg Bachmann's Literary Critique of the Journalistic Media, doctoral dissertation, Department of Germanic Studies, The University of Sydney, Sydney 2008, s. 195, https://core.ac.uk/download/pdf/41233687.pdf (24.11.2016).

I. Bachmann Ein Maximum an Exil..., s. 446.

36 Tamże, s. 440, 442-443. 
w całej literaturze polskiej - nie domyka narracji ani nawet nie doprowadza jej do wzniosłego zwieńczenia. Antycypując nieskończenie odległy, kamienny spokój śmierci w samym środku permanentnej agonii ciała-klozetu zamurowanego w samym sobie, zdanie to rozbija zarówno ułudę spoistości znaczeń, jak i powszechność rozbicia, każe nam bowiem skupić się na absolutnie pojedynczym punkcie cierpienia - i odbiera zdolność dalszej lektury. Na koniec przeczytajmy więc raz jeszcze: „I wtedy wejdą zwierzęta do twojego pokoju i siądą na tobie spokojnie, jak na kamieniu i ziemi".

\section{Abstract}

\section{Adam Lipszyc}

INSTITUTE OF PHILOSOPHY AND SOCIOLOGY OF THE POLISH ACADEMY OF SCIENCES

A Part of Death: Passive Frankism and Black Gnosis in Leo Lipski's Piotruś

Ingeborg Bachmann's draft for a review of the micro-novel Piotruś by Leo Lipski allows Lipszyc to portray the world represented in the Polish-Jewish emigre writer's work as a space of Babel-like chaos that revolves around the anal sphere inhabited by the protagonist's deformed body. The messianic motifs woven into the text - subtitled '(apokryf)' or apocryph) - cannot be read uncritically. Lipszyc juxtaposes the theology of Piotruś with Jakub Frank's ideas, suggesting that the protagonist Piotruś embodies a paradoxical 'passive Frankism' who walks the path of 'black horror'. This path offers no redemption but brings us in touch with 'a part of death' - a point in our soul where we remain entirely opaque to ourselves. Even though the protagonist himself is headed for destruction, as a literary figure he is a sign of the singularity of suffering.

\section{Keywords}

Leo Lipski, Ingeborg Bachmann, anality, messianism, Frankism 